\title{
Correction to: imaging of complications following Fontan circulation in children-diagnosis and surveillance
}

\section{Charlotte de Lange ${ }^{1,2}$}

Published online: 20 August 2020

(C) Springer-Verlag GmbH Germany, part of Springer Nature 2020

Correction to: Pediatric Radiology (2020)

https://doi.org/10.1007/s00247-020-04682-5

In the original version of this paper there was an inadvertent misnumbering of references. These issues have been corrected in the current version of the paper. The Original article has been corrected.

Publisher's note Springer Nature remains neutral with regard to jurisdictional claims in published maps and institutional affiliations.

The online version of the original article can be found at https://oi.org/ $10.1007 / \mathrm{s} 00247-020-04682-5$

Charlotte de Lange

charlotte.de.lange@vgregion.se; charlotte.delange@medisin.uio.no

1 Department of Radiology and Clinical Physiology, Queen Silvia Children's Hospital, Rondv.10, S-41516 Gothenburg, Sweden

2 Department of Radiology and Nuclear Medicine, Oslo University Hospital, Oslo, Norway 